\title{
RADIOCARBON DATING IN LATE-ROMAN AND MEDIEVAL CONTEXTS: AN ARCHAEOLOGICAL EXCAVATION IN THE CENTER OF FLORENCE, ITALY
}

\author{
M E Fedi ${ }^{1,2} \bullet$ A Arnoldus-Huyzendveld ${ }^{3} \cdot$ A Cartocci $^{1} \bullet$ M Manetti $^{1} \bullet \mathrm{F}$ Taccetti $^{1}$
}

\begin{abstract}
A series of samples for radiocarbon dating were collected in 2005 from the Biblioteca Magliabechiana archaeological excavation area in the center of Florence, Italy, in a project directed by the Dipartimento di Archeologia e Storia delle Arti of the University of Siena, in cooperation with the Soprintendenza per i Beni Architettonici e per il Paesaggio per le province di Firenze e Prato. This area is located near the Uffizi Galleries, close to the Roman town, the Arno River and one of its former tributaries. The area is peculiar for the Florentine urban context because it was free from urban development until the 12th century AD. The exposed stratigraphy showed the presence of several layers composed of natural sediments, partly the result of historical floods. Here, we report a series of ${ }^{14} \mathrm{C}$ measurements on charcoal and seed samples collected on this excavation. ${ }^{14} \mathrm{C}$ dating has been performed in the LABEC laboratory in Florence, on the accelerator mass spectrometry (AMS) beam line of the AMS-IBA 3MV Tandetron accelerator. We also had the opportunity to compare the ${ }^{14} \mathrm{C}$ dates obtained with several series of samples previously collected in nearby archaeological areas. Results were consistent with the data obtained previously and, moreover, offer interesting new aspects to the interpretation of the archaeological findings.
\end{abstract}

\section{INTRODUCTION}

The Biblioteca Magliabechiana site (see Figure 1) is located to the southeast of the Uffizi Galleries in Florence, Italy, less than $100 \mathrm{~m}$ from the Arno River. Archaeological excavations were undertaken in 2005 by the Dipartimento di Archeologia e Storia delle Arti of the University of Siena, under the direction of Prof Riccardo Francovich and Prof Federico Cantini, in cooperation with the Soprintendenza per i Beni Architettonici e per il Paesaggio per le province di Firenze e Prato. The excavations were related to the foreseen re-arrangement of the Uffizi Galleries. The stratigraphy of this site, as well as that of the nearby Via de' Castellani site (Cantini et al., forthcoming), is characterized by the absence of Roman constructions and by the presence of various natural and cultural layers predating the reconstruction of the city in the 12th century. Some of these layers are evidently related to the frequent floods (registered in Florence from the 12th century on), as demonstrated by their layered structure and homogenous texture. The Arno, which cuts through Florence, is a braiding river, and thus is characterized by a quite unpredictable hydraulic regime. Moreover, this area of the town may well have been particularly exposed to the highest flood impact, not only because of its position directly downstream of the open valley and the presence of the city walls and river embankments, but also because of the general morphological and geological structure of the valley (Arnoldus-Huyzendveld, forthcoming).

Generally, flood sediments tend not to be preserved in the archaeological record since they are either removed by human activity or washed away by successive events. In this particular area of the town, the layers were trapped in a small sedimentation basin delimited by the embankments of the Arno River and one of its former tributaries, and also by the slightly upsloping gradient of the natural relief upon which the town was founded. For the same reason, particular layers ("dark earths") could slowly accumulate and remain well preserved in this area.

'Dipartimento di Fisica dell'Università di Firenze and INFN Sezione di Firenze, via Sansone 1, 50019 Sesto Fiorentino (Fi), Italy.

${ }^{2}$ Corresponding author. Email: fedi@fi.infn.it.

${ }^{3}$ Dipartimento di Archeologia e Storia delle Arti, Università di Siena, Via Roma 56, 53100 Siena, Italy. 


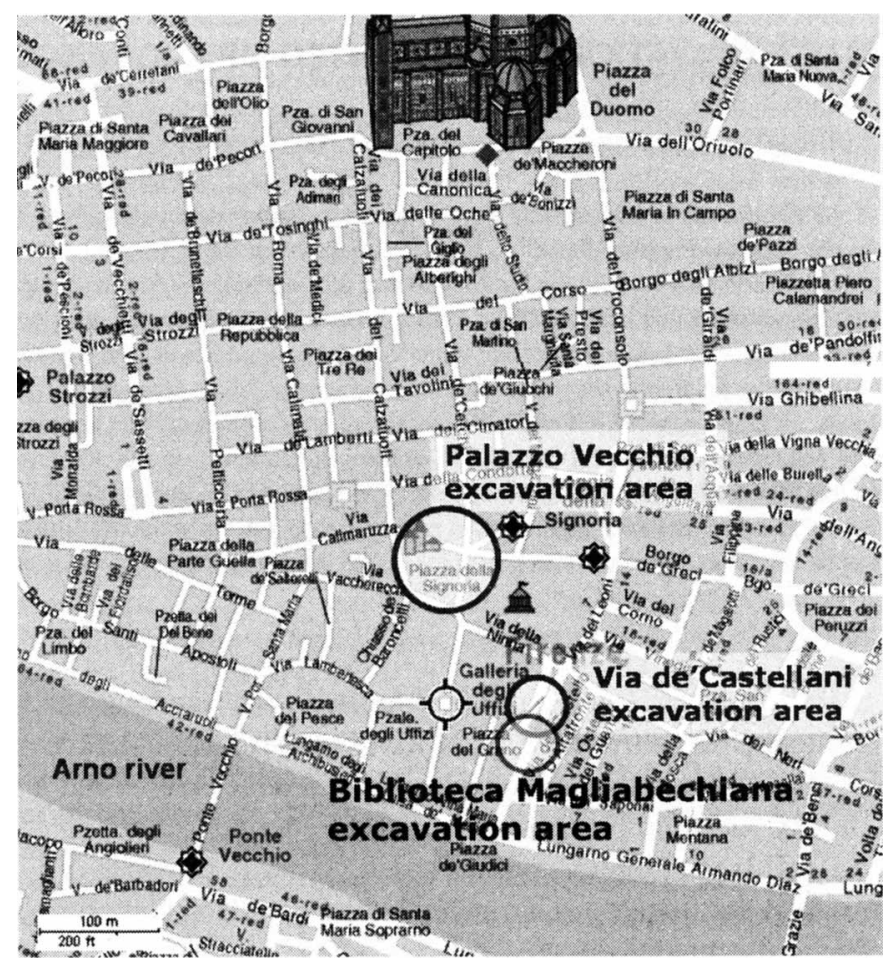

Figure 1 Map of the excavation site: the Biblioteca Magliabechiana lies in the area of the Uffizi Galleries, in the center of Florence. The 2 excavation sites of Palazzo Vecchio and Via de' Castellani are also shown.

\section{METHODS}

We have collected charcoal and seed samples for radiocarbon dating. The samples can be divided into 3 different groups: in the first group, 6 samples (see Figure 2) were taken from a succession of stratigraphic units that we have called sequence "Q" (in this case, 2 samples have been considered as disturbed, since their dates were highly inconsistent with the others); in the second group, 5 samples were taken from a different sequence, called "Pozzo." In the third group, we have considered all the other samples taken from other stratigraphic units in the Biblioteca Magliabechiana site, but not related to specific sequences. On the basis of archaeological evidence, the age range expected was between the early Medieval period and the 12th century. Measurements have been performed on the accelerator mass spectrometry (AMS) beam line of the 3MV Tandetron accelerator of LABEC in Florence (Fedi et al. 2007).

Both charcoal and seed samples were pretreated according to the acid-alkali-acid (AAA) method using $1 \mathrm{M} \mathrm{HCl}$ and $0.1 \mathrm{M} \mathrm{NaOH}$ solutions. During the acid baths, the samples were heated to about $80^{\circ} \mathrm{C}$, while the alkaline step was performed at room temperature to avoid charcoal desegregation. In our laboratory, sample combustion is performed using an elemental analyzer (Thermo EA Flash1112), whose outlet, after the gas-chromatographic column, is directly coupled to the graphitization line. There, the sample $\mathrm{CO}_{2}$ is collected in a stainless steel trap dipped in liquid nitrogen and then transferred to one of the 4 graphitization reactors, where it is reduced to elemental graphite by reaction with hydrogen in the presence of iron as catalyst (Vogel et al. 1984). 


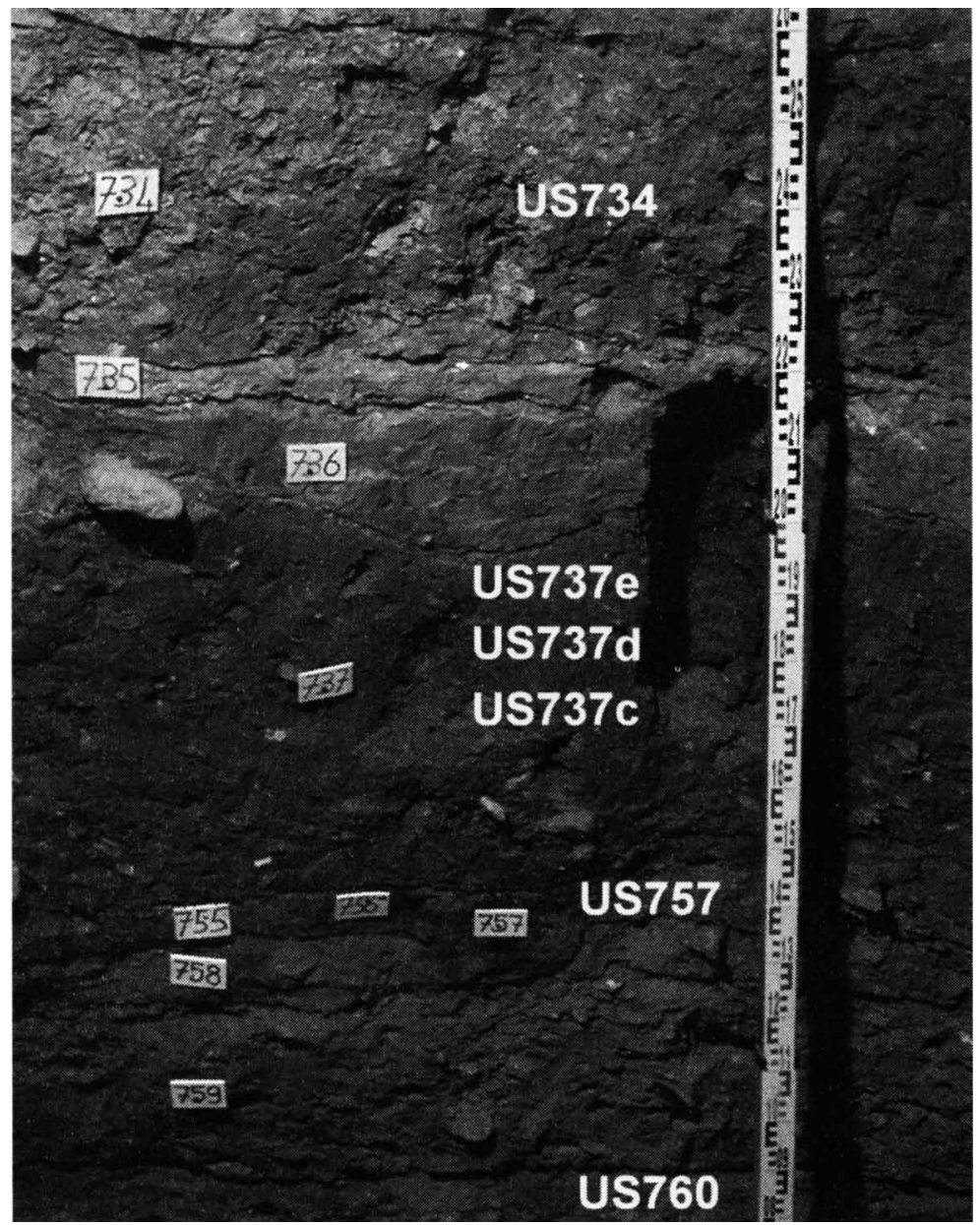

Figure 2 Photograph of the stratigraphy of one side of the excavation site of Magliabechiana: the stratigraphic units of the section $Q$ are indicated.

The AMS beam line of the LABEC Tandetron is equipped, on the low-energy side, with an electrostatic analyzer and a bouncer magnet for sequential injection, and, on the high-energy side, with magnetic and electrostatic analysis. ${ }^{12} \mathrm{C}$ and ${ }^{13} \mathrm{C}$ isotopes are measured by 2 offset Faraday cups after the high-energy magnet; ${ }^{14} \mathrm{C}$ ions are counted in an ionization chamber filled with butane. Measured ${ }^{14} \mathrm{C} /{ }^{12} \mathrm{C}$ ratios in unknown samples are corrected for isotopic fractionation and for background events and normalized to NIST oxalic acid II. ${ }^{14} \mathrm{C}$ ages are converted to calibrated ages using OxCal v 3.10 (Bronk Ramsey 1995, 2001) using the IntCal04 calibration curve (Reimer et al. 2004).

\section{RESULTS AND DISCUSSION}

Tables 1 and 2 summarize all the data discussed in this paper. When dealing with samples collected from the sequences $\mathrm{Q}$ and Pozzo, calibration of ${ }^{14} \mathrm{C}$ ages was performed using the Sequence and Phase models of the software OxCal. 
Table 1 Summary of the results for the samples in the 2 analyzed sequences; the ${ }^{14} \mathrm{C}$ ages are quoted at $1-\sigma$ uncertainty.

\begin{tabular}{|c|c|c|c|c|c|}
\hline Sample code & Material & $\begin{array}{l}\text { Stratigraphic } \\
\text { unit }\end{array}$ & Notes & ${ }^{14} \mathrm{C}$ age (BP) & $\begin{array}{l}\text { Cal age (AD) } \\
1 \sigma\end{array}$ \\
\hline \multicolumn{6}{|l|}{ Sequence $\mathbf{Q}$} \\
\hline FBM05_30 & charcoal & US760 & flooding sediment & $1495 \pm 100$ & $540-650$ \\
\hline FBM05_29 & charcoal & US757 & fire layer & $1390 \pm 22$ & $640-665$ \\
\hline FBM05_23 & charcoal & US737c & “dark layer" & $1340 \pm 22$ & $655-680$ \\
\hline FBM05_22 & charcoal & US737d & "dark layer" & $1090 \pm 70$ & $890-995$ \\
\hline FBM05_21 & seed & US737e & "dark layer" & $1080 \pm 45$ & $\begin{array}{l}895-925(25 \%) \\
935-995(43 \%)\end{array}$ \\
\hline FBM05_31 & charcoal & US734 & infill & $970 \pm 25$ & $\begin{array}{l}1020-1050(34 \%) \\
1090-1130(30 \%) \\
1140-1150(4 \%)\end{array}$ \\
\hline \multicolumn{6}{|c|}{ Sequence Pozzo } \\
\hline FBM05_06 & charcoal & US581 & flooding sediment & $1770 \pm 40$ & $220-350$ \\
\hline FBM05_05 & charcoal & US577 & "dark layer" & $1030 \pm 25$ & $980-1020$ \\
\hline FBM05_03 & charcoal & US573 & infill & $\begin{array}{l}1535 \pm 55 \\
\text { (offset } 450 \pm 20 \text { ) }\end{array}$ & $990-1040$ \\
\hline FBM05_02 & seed & US480 & fire layer & $990 \pm 27$ & $\begin{array}{l}1010-1050(55 \%) \\
1090-1120(13 \%)\end{array}$ \\
\hline FBM05_01 & charcoal & US445 & flooding sediment & $960 \pm 27$ & $\begin{array}{l}1030-1050(10 \%) \\
1090-1160(58 \%)\end{array}$ \\
\hline
\end{tabular}

Samples from section Q were analyzed as a sequence, considering samples FBM05_23, FBM05_22, and FBM05_21 (extracted at regular 10-cm intervals from a so-called "dark layer") as part of the same phase, and good agreement was obtained. Samples from the Pozzo section were also analyzed in a sequence; in this case, in order to obtain a satisfactory agreement, we had to add a wide offset age to the sample FBM05_03. This can, however, be explained, since the associated layer consisted of fill material; in such a layer, there can be samples of very different ages, also much older than what is expected from the stratigraphy itself. The other data collected in Table 2 are interesting because they can be associated with the same events that characterize the sequences: for example, samples FBM05_08 and FBM05_20, collected from flooding sediments, can be associated with sample FBM05_01 in the Pozzo sequence.

Table $2{ }^{14} \mathrm{C}$ ages of other samples from the same excavation site; the ${ }^{14} \mathrm{C}$ ages are quoted at $1-\sigma$ uncertainty.

\begin{tabular}{llllr}
\hline Sample code & Material & Stratigraphic unit & Notes & ${ }^{14}$ C age (BP) \\
\hline FBM05_11 & seed & US423 & fire layer & $1050 \pm 26$ \\
FBM05_18 & seed & US558 & fire layer & $860 \pm 20$ \\
\hline FBM05_08 & seed & US561 & infill / flooding sediment & $960 \pm 37$ \\
FBM05_09 & charcoal & US416 & infill / flooding sediment & $1015 \pm 25$ \\
FBM05_20 & charcoal & USK-B & flooding sediment & $940 \pm 50$ \\
\hline FBM05_16 & charcoal & US613 & "dark layer" & $1150 \pm 90$ \\
\hline
\end{tabular}

Through these measurements, we have investigated a fairly large span of time, from the 3rd century AD (see sample FBM05_06 in the section Pozzo taken from a flooding sediment) to the 12th century AD. In this period, this area of Florence was indeed affected by several fires and floods. 
We can identify 3 different phases associated with fires: one (sample FBM05_29 in section Q) in the first half of the 7th century; a second (sample FBM05_02 in section Pozzo and sample FBM05_11) in the first half of the 11th century; and a third (sample FBM05_18) in the second half of the 12th century. We find confirmation of this last event in historical chronicles where a great fire in August 1177 is mentioned (Losacco 1967).

By dating samples from alluvial sediments, we have dated 3 different floods (or periods of intensive flooding): the oldest (sample FBM05_06 in section Pozzo) in the 3rd to 4th century; then one (sample FBM05_30 in section Q) in the 6th-7th century; and the most recent (sample FBM05_01 in section Pozzo and samples FBM05_08, FBM05_09, FBM05_20) in the 12th century. Drawing a comparison between the ${ }^{14} \mathrm{C}$ data and the historical data is essential. Even though no specific information on this topic is available for Florence for this period, in other locations of central and northern Italy a strong flood was registered in AD 589 (Brogiolo and Gelichi 1998): sample FBM05_30 is actually consistent with this historical record. Moreover, an alluvial layer encountered in the nearby Via de' Castellani excavation area has been assigned to the same natural event: sample Castellani_US623, $1619 \pm 27$ BP (see Arnoldus-Huyzendveld, forthcoming).

The first flood mentioned in the historical sources of medieval Florence is a catastrophic one that occurred in 4 November 1177 (Losacco 1967). Samples FBM05_01, FBM05_08, FBM05_09, FBM05_20, and their corresponding sediment layers thus can be associated with this flood, or with earlier floods in the same century. Moreover, a comparison can be made between these data and 2 dates from nearby excavations: sample P.Vecchio_US188 (954 \pm 23 BP; Arnoldus-Huyzendveld, forthcoming) from a flooding sediment in the excavation area of Palazzo Vecchio and sample Castellani_US570 (882 \pm 24 BP; Arnoldus-Huyzendveld, forthcoming) from an alluvial sediment too in the excavation area of Via de' Castellani are in good agreement with the data discussed here, as can be seen from the OxCal plot of the phase in Figure 3.

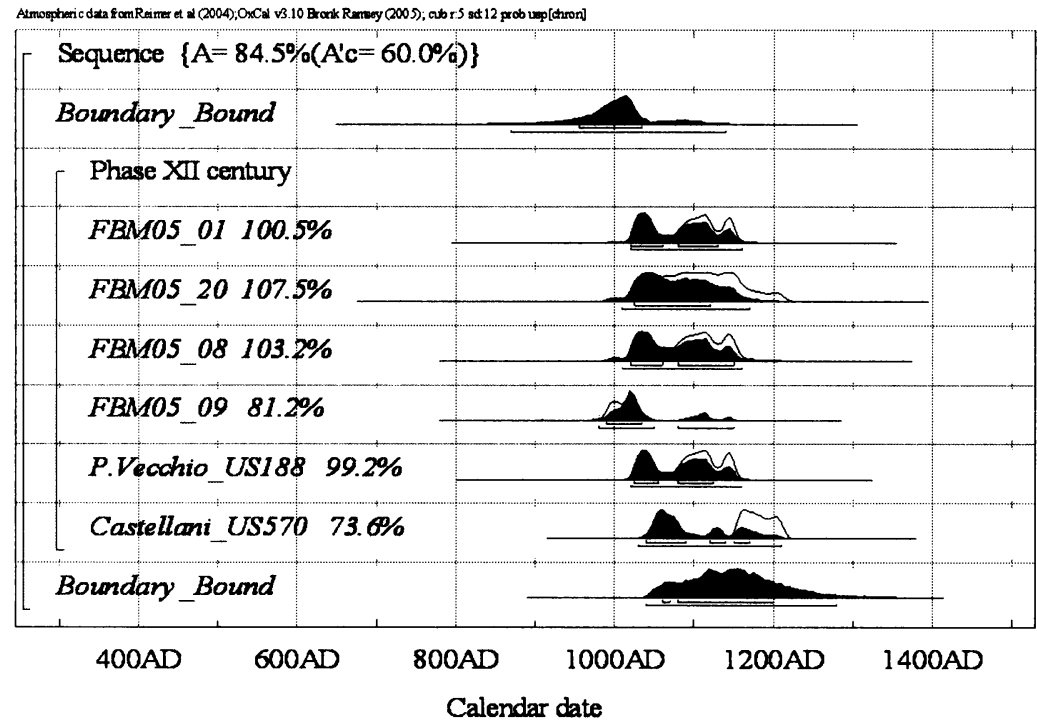

Figure 3 Plot of the a posteriori distributions of probability for the calendar ages of samples that can be considered of the same phase, probably the period of the fire and the huge flood of AD 1177. 
Dated samples also come from the so-called dark layers, typical in early medieval urban contexts (Brogiolo and Gelichi 1998). In this case, they seem to be formed in a time span of about $400 \mathrm{yr}$ and concentrated in 2 phases, namely the 7th and 10th centuries. It is interesting to note that the chronological gap between the phases has its counterpart in a lower ceramic density at the excavation (Cantini et al., forthcoming).

\section{REFERENCES}

Arnoldus-Huyzendveld A. Forthcoming. Tra terra e acqua: trasformazioni geo-ambientali. In: Cantini F, Cianferoni C, Francovich R, Scampoli E, editors. Forthcoming. Firenze Prima Degli Uffizi. Lo Scavo di Via de' Castellani. Contributi per un'Archeologia Urbana fra Tardo Antico ed età Moderna. Florence: All'Insegna del Giglio. In Italian.

Brogiolo GP, Gelichi S. 1998. La Città Nell'alto Medioevo Italiano: Archeologia e Storia. Rome: Laterza. In Italian.

Bronk Ramsey C. 1995 Radiocarbon calibration and analysis of stratigraphy: the OxCal program. Radiocarbon 37(2):425-30.

Bronk Ramsey C. 2001. Development of the radiocarbon calibration program. Radiocarbon 43(2A):355-63.

Cantini F, Cianferoni C, Francovich R, Scampoli E, editors. Forthcoming. Firenze Prima Degli Uffizi. Lo Scavo di Via de' Castellani. Contributi per un'Archeologia Urbana fra Tardo Antico ed età Moderna. Florence: All'Insegna del Giglio. In Italian.

Fedi ME, Cartocci A, Manetti M, Taccetti F, Mandò PA. 2007. The ${ }^{14} \mathrm{C}$ AMS facility at LABEC, Florence. $\mathrm{Nu}$ clear Instruments and Methods in Physics Research $B$ 259(1):18-22.
Francovich R, Cantini F. 2006. Nuovi dati sulla cultura materiale della città di Firenze tra età imperiale ed altomedioevo: i contesti dello scavo di Via de' Castellani. In: Francovich R, Valenti M, editors. IV Congesso Nazionale di Archeologia Medievale. Florence: All'Insegna del Giglio. p 132-5. In Italian.

Losacco U. 1967. Notizie e considerazioni sulle inondazioni d'Arno a Firenze. L'Universo 5:4-104. Florence: Istituto Geografico Militare. In Italian.

Reimer PJ, Baillie MGL, Bard E, Bayliss A, Beck JW, Bertrand CJH, Blackwell PG, Buck CE, Burr GS, Cutler KB, Damon PE, Edwards RL, Fairbanks RG, Friedrich M, Guilderson TP, Hogg AG, Hughen KA, Kromer B, McCormac G, Manning S, Bronk Ramsey C, Reimer RW, Remmele S, Southon JR, Stuiver M, Talamo S, Taylor FW, van der Plicht J, Weyhenmeyer CE. 2004. IntCal04 terrestrial radiocarbon age calibration, 0-26 cal kyr BP. Radiocarbon 46(3): 1029-58.

Vogel JS, Southon JR, Nelson DE, Brown TA. 1984. Performance of catalytically condensed carbon for use in accelerator mass spectrometry. Nuclear Instruments and Methods in Physics Research B 5(2): 289-93. 